\title{
混合構造接合部の強度と剛性に関する実験的研究 EXPERIMENTAL STUDY ON THE STRENGTH AND THE STIFFNESS OF JOINTS IN MIXED STRUCTURES
}

\author{
飯塚信一*，笠松照親**，野口博*** \\ Shin-ichi IIZUKA, Teruchika KASAMATSU and Hiroshi NOGUCHI
}

\begin{abstract}
In order to simplify a joint for concrete casting and constructions for mixed structure, the details of the joint with a reinforced concrete column and steel beams of a mixed structure were developed. The objects of this study were to evaluate the ultimate shear strength and to investigate the shear resisting mechanisms and the shear stiffness of the joint. The developed joint details showed desireble seismic behavior for the ultimate strength and the ductility in the test. The steel end plates of lateral beams contributed to the shear resisting mechanisms of the joint. The shear strength formula of the joint was discussed, and the confined effect of concrete and the effective sectional area of the joint were evaluated. Based on the experimental results, the shear stiffness of the joint was discussed, and the shear force - deformation characteristics of the joint was proposed.
\end{abstract}

Ke ywords : mixed st ruc ture, be am-column joint, maximum shear st rength, stiffness

混合構造、柱梁接合部、最大せん断耐力、㓮性

\section{1.はじめに}

近年、施工の合理化、省力化を目的とした構法が盛ん に研究されている。その中でむ、柱を鉄筋コンクリート $(R C)$ 造、梁を鉄骨 $(S)$ 造とした混合構造の研究が 種々の機関で研究開発されている。柱をコンクリート系、 梁を鉄骨系とする混合構造では、鉛直方向の軸力をコン クリート系柱で受け持ち、鉄骨梁による長スパンの空間 を形成するという構造的利点がある。さらには、施工方 法を検討することで、一般の鉄筋コンクリート造に比べ 工期短縮を図ることも可能である。

柱 $\mathrm{RC}$ 造、梁 $\mathrm{S}$ 造で構成された混合構造では、異種部 材の交錯する接合部の抵抗機構を检討することが重要な 問題となる。そして、このような混合構造を設計するに あたっては、接合部の強度と剛性を適切に評価すること が必要である。

接合部の形状は、一般に梁貫通型と柱貫通型に大別で きる。梁貫通型はS R C 造を基本に考えられたすのであ
り、柱貫通型は $\mathrm{R} C$ 造の接合部を基本に考えられている。 梁貫通型は、鉄骨梁が接合部を貫通したすのであり、 接合部内の応力の伝達を接合部内梁フランジの支圧力、 梁ウェプのせん断力と接合部コンクリート圧縮ストラッ トにより負担する機構である。

西村、南1) は、単純な梁貫通型試験体を用いて、てこ 機構に基づく接合部の応力伝達機構を検討し、梁フラン ジに接するコンクリートの支圧強度を考慮した接合部酎 力式を提案している。

坂口2)は、梁貫通型試験体の接合部廻りを鋼板でふさ ぐことにより、接合部の強度と剛性を高める工夫をして いる。そして、接合部の応力伝達機構を検誩し、接合部 せん断強度を接合部コンクリート、鉄骨ウェプ、外周鋼 板の各部材負担強度の昭加として提案している。

一方、柱貫通型は、鉄骨梁を柱面位置で寸断し、接合 部超りに応力伝達部材を配固しているもので、その部材 と内部の R C 接合部とで応力を負担する機構である。

\footnotetext{
本論文の一部は, 文献 5) に発表したものである。

*千葉大学 大学院生 (西松建設技術研究所)

** 西松建設技術研究所

****千葉大学工学部建築学科 教授. I博
}

Graduate Student Chiba Univ. (Technical Research and Development Institute, Nishimatsu Construction)

Technical Research and Development Institute, Nishimatsu Construction

Prof., Dept. of Architecture, Faculty of Engineering, Chiba Univ., Dr. Eng. 
佐藤等 (2) は、鋳鉄製のダイアフラムと鋼管とを組み合 わせた柱貫通型の接合部仕口により、接合部を鋼管コン クリート構造として帮価している。

筆者等は、コンクリート充泻の為の施工性と鉛直ス天 フナで拘束された $\mathrm{R} C$ 接合部のせん断抵抗機棈を考慮し た柱貫通型の新しい柱 $\mathrm{R} C$ 造、梁 $\mathrm{S}$ 造の混合構造接合部 の仕口を開発しだ25)。接合部ディテールの特徽は、接 合部内は、梁フランジを鉛直スチフナ（中板ウェブ）に 置き換元、接合部内における接合部中央の中板ウェブを 取り除いた R C 系接合部であり、耐震性能に優れた仕口 形状であることを確虫した。

本研究では、接合部仕口を構成する要素部材をパラメ 一タとした実験を行い、接合部のせん断抵抗機棈を検討 し、接合部せん断強度と変形の定量化を行い、接合部の 剛性を検討することにより混合構造接合部の復元力特性 を提案することを目的とするすのである。

\section{2. 実稌概要}

2. 1 試験体

本研究では、接合部形状のみをパラメータとして実駼 を行った。接合部仕口は、図 1 亿示すように、柱面位置 のエンドプレート、梁フランジ位置でエンドプレートを つなぐ上下の中板、斜めスチフナで棈成されており、接 合部内中央部分に中板は無い形状が基本である。

試験体形状を図 2 (a)に、試験体諸元を表 1 に示す。試

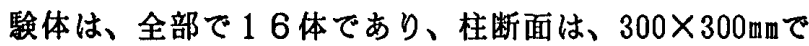
全試験体共通であり、梁は、梁成の異なる I 1（250mm） 以外、全試験体共通 $(H-200 \times 100 \times 12 \times 16)$ である。

試験体は、接合部を構成する各部材の応力伝達機構を 検討することを目的とするために、梁降伏後の接合部破 壊型を目標とした柱、梁部材断面とし、接合部部材は、 表2に示すように構成されている。

A 1、A 2 は、同一形状であり、接合部中央のウェフ 部分を取り除き、梁フランジと同じ大きさの上下の中板 と斜めスチフナがエンドプレートに取り付いた試驗体で、 本研究の基本的形状である。

B 1 は、Aタイプに比べ中板の厚さを1.2倍、斜めスチ フナの厚さを 0.75 倍し、中板の応力負担分を検討する。

C 1 は、Aタイブに比ベェンドプレートの厚さを1.4倍 し、エンドプレートの応力負担分を検討する。

D 1 は、エンドプレートの長さを梁上下方向に長くし たむの、E 1 は、中板とエンドプレートとの接合部分に 三角形リブを取り付けたもので、コンクリートの圧縮ス トラットの効果を検討する。

F 1 は、Aタイプの斜めスチフナの無い試験体、G 1 は、Aタイプのエンドプレート中央部分が無い試戨体、 H 1 は、Aタイプの直交方向中板の無い試駼体であり、
各部材の負担力を㭘討する。

I 1 は、梁成を $250 \mathrm{~mm}$ と大きくし梁成の影響を検討する。 $\mathrm{J} 1 、 \mathrm{~J} 2$ は、同一形状であり、接合部中央に中板ウ ェブが有る試験体で、中板ウェブの勃果を検討する。

K 1、L 1 は、本研究の試験体と比較するための試駼 体で、K 1 は、エンドプレートをP C 鋼棒で締好付けた 試験体であり、L 1 は、鉄骨梁が貫通した試験体である。

$\mathrm{T} 1 、 \mathrm{~T} 2$ は、卜型試験体であり、接合部内形状は、 Aタイプと同一である。T 1 は、普通強度コンクリート、 $\mathrm{T} 2$ は、高強度コンクリート $\left(\mathrm{Fc}=800 \mathrm{kgf} / \mathrm{cm}^{2}\right)$ とした試 験体である。

\section{2 使用材料および実験方法}

実験に用いたコンクリート、鉄筋、鉄骨の材料特性を 表 3 に示す。

コンクリートは、設計基準強度 $\mathrm{Fc}=240 \mathrm{kgf} / \mathrm{cm}^{2}$ のレ ミクストコンクリートである。K 1 では、 P C 鋼棒締め 付けのために $\mathrm{Fc}=300 \mathrm{kgf} / \mathrm{cm}^{2}$ を T 2 では、高強度コンク リートとして $\mathrm{Fc}=800 \mathrm{kgf} / \mathrm{cm}^{2}$ 目標とした。

実験時のコンクリート強度は、 $\mathrm{Fc}=240 \mathrm{kgf} / \mathrm{cm}^{2}$ のむので 約 $280 \mathrm{kgf} / \mathrm{cm}^{2} 、 \mathrm{~K} 1$ が $350 \mathrm{kgf} / \mathrm{cm}^{2} 、 \mathrm{~T} 2$ が $880 \mathrm{kgf} / \mathrm{cm}^{2}$ 程

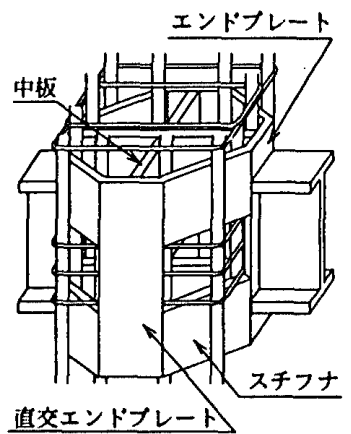

図 1 接合部仕口形状

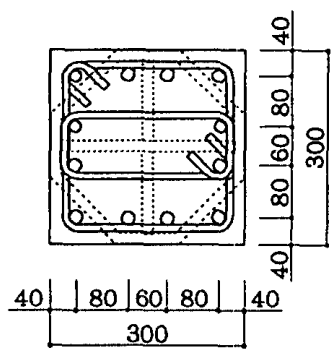

図2(b) 柱断面

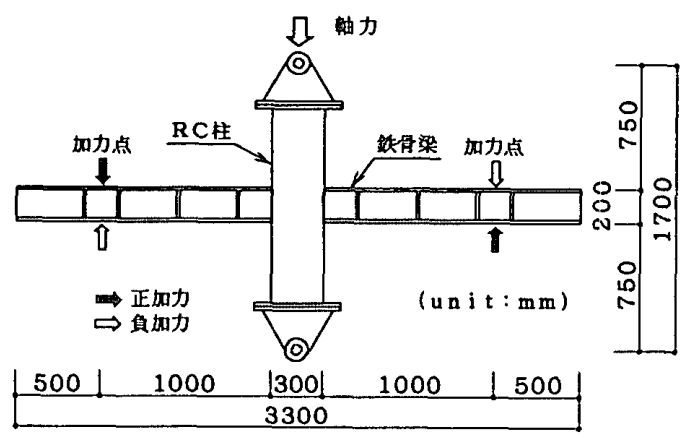

図2（a）試驗体形状

表 1 試験体諸元

\begin{tabular}{|c|c|c|}
\hline \multirow{4}{*}{ 柱 } & 断面 & $\mathrm{b} \times \mathrm{D}=300 \times 300(\mathrm{~mm})$ \\
\hline & 主筋 & $12-\mathrm{D} 19(\mathrm{pt}=1.28 \%)$ \\
\hline & 帯筋 & $4-\mathrm{D} 10 @ 50 \quad(\mathrm{pw}=1.9 \%)$ \\
\hline & 軸力 & $0.2 \mathrm{bD} \sigma_{\mathrm{B}}\left(\mathrm{A} 2, \mathrm{~J} 2=0.1 \mathrm{bD} \sigma_{\mathrm{B}}, \mathrm{T} 1, \mathrm{~T} 2=\right.$ 無し) \\
\hline 梁 & 断面 & $\begin{array}{l}\mathrm{H}-200 \times 100 \times 12 \times 16 \text { (mm) } \\
\mathrm{H}-250 \times 100 \times 12 \times 16 \quad(\text { I 1) } \\
\end{array}$ \\
\hline & & $4-D 6 @ 50(p w=0.85 \%)$ \\
\hline
\end{tabular}


表 2 接合部諸元
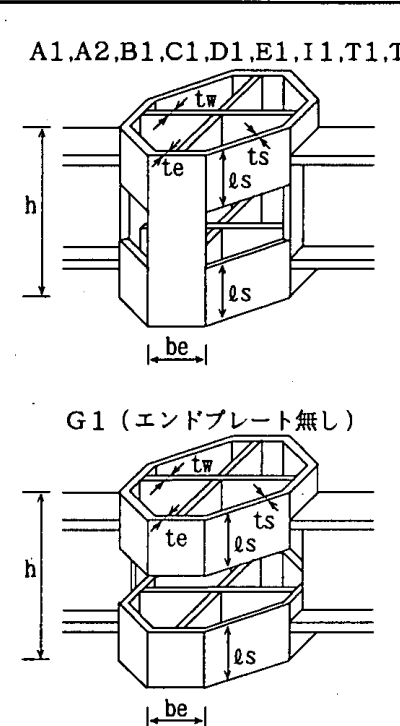

J 1，J2（中板ウェブ有り）

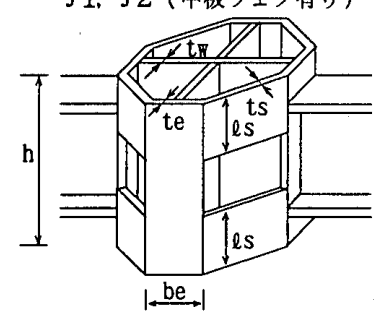

$\mathrm{K} 1$ (PC鈰棒締め)

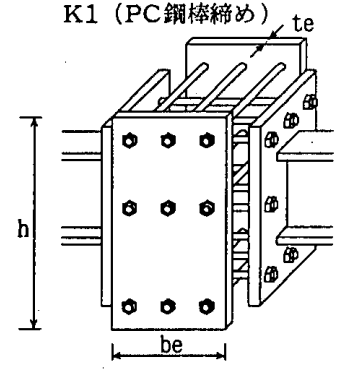

H1（淔交力向中板無し）
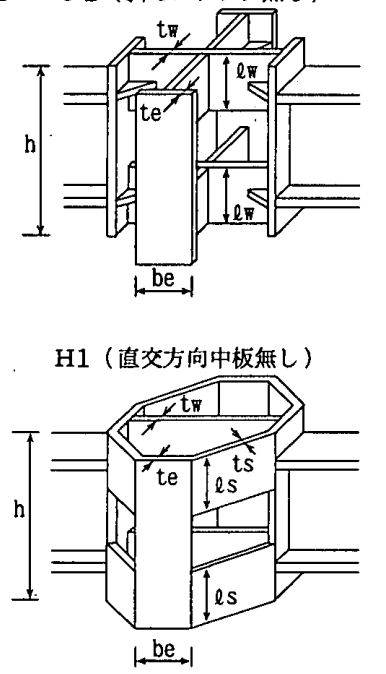

L1 (梁貫通型)

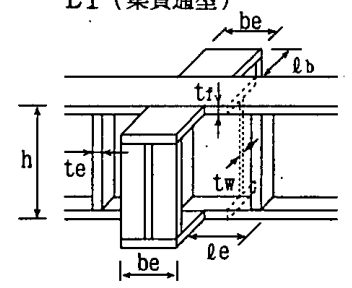

K1ボルト位直

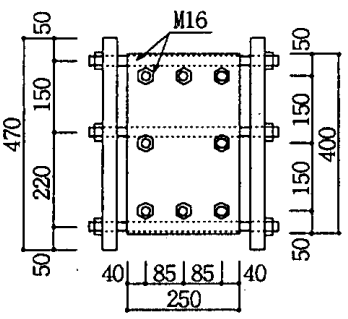

仕口構成部材寸法

\begin{tabular}{|c|c|c|c|c|c|c|c|c|}
\hline & $\mathrm{h}$ & be & $\mathrm{ls}$ & $\ell w$ & tw & ts & te & \\
\hline $\begin{array}{l}\text { A } 1 \\
\text { A } 2\end{array}$ & 300 & 100 & 100 & 100 & 16 & 16 & 16 & 基本形状 \\
\hline B 1 & 300 & 100 & 100 & 100 & 19 & 13 & 16 & 中板厚大 \\
\hline C 1 & 300 & 100 & 100 & 100 & 16 & 16 & 22 & エンドプレート厚大 \\
\hline D 1 & 350 & 100 & 100 & 100 & 16 & 16 & 16 & エンドプレート長大 \\
\hline E 1 & 300 & 100 & 100 & 100 & 16 & 16 & 16 & 三角りブ付き \\
\hline F 1 & 300 & 100 & - & 100 & 16 & - & 16 & 斜めスチフ十無し \\
\hline G 1 & 300 & 100 & 100 & 100 & 16 & 16 & 16 & エンドプレート無し \\
\hline H 1 & 300 & 100 & 100 & 100 & 16 & 16 & 16 & 直交方向中板無 U \\
\hline I 1 & 350 & 100 & 100 & 100 & 16 & 16 & 16 & 梁成大 \\
\hline $\begin{array}{ll}\mathrm{J} & 1 \\
\mathrm{~J} & 2\end{array}$ & 300 & 100 & 100 & 300 & 16 & 16 & 16 & 中板ウェブ有り \\
\hline $\begin{array}{ll} & 1 \\
\text { T } & 2\end{array}$ & 300 & 100 & 100 & 100 & 16 & 16 & 16 & 卜型試験体 \\
\hline & $h$ & be & - & - & - & - & te & \\
\hline K 1 & 400 & 250 & - & - & - & - & 25 & P C 鋼棒締め \\
\hline & $\mathrm{h}$ & be & $\mathrm{lb}$ & $l \mathrm{e}$ & tw & ts & te & \\
\hline L 1 & 200 & 100 & 100 & 100 & 12 & 16 & 16 & 梁貫通型 \\
\hline
\end{tabular}

度であった。

鉄筋および鉄骨は、全試験体、共通の材料を使用して いる。柱主筋には、12-D19(SD345, $\left.\mathrm{p}_{\mathrm{t}}=1.28 \%\right) 、$ 柱帯筋に は、4-D10(SD345, $\left.\mathrm{p}_{\mathrm{w}}=1.9 \%\right)$ 、接合部内せん断補強箭には、 4-D6 (SD295, $\left.\mathrm{p}_{\mathrm{w}}=0.85 \%\right) 、$ 梁鉄骨および接合部仕口部材に は、SS400を使用した。

加力装置を図 3 に示す。加力は、 $500 \mathrm{tf}$ 定軸力装置によ り柱頂部に一定軸力 (A 2、J 2 は、 $0.1_{\mathrm{C}} \sigma_{\mathrm{B}} \mathrm{bD}$ 、他は、 $\left.0.2_{\mathrm{C}} \sigma_{\mathrm{B}} \mathrm{bD}\right)$ を載荷後、100tfアクチュエータを用いて両 側の梁に逆対称正負繰り返し加力を行った。なお、卜型 試験体 T 1、T 2については、軸力無しとした。

載荷履歴は、層間部材角 $R=1 / 200 \mathrm{rad}$. で 1 回、 $R=1 / 100$ 、 $1 / 50 、 1 / 33 \mathrm{rad} . て ゙$ 各 2 回の繰り返し後、最後に正側のみ $\mathrm{R}=1 / 25 \mathrm{r}$ ad.の加力を行った。A 2 試験体は、加力装置の 故障により $\mathrm{R}=1 / 33 \mathrm{rad}$.で実験を終了した。

各部材の変形および風間変形は、図 4 に示すような接 合部内の柱軸線上に取り付けた十字型測定フレームを用

表 3 材料特性

\begin{tabular}{|c|c|c|c|c|}
\hline エンクリ & & $\begin{array}{l}\text { 圧縮強度 } \\
\left(\mathrm{kgf} / \mathrm{cm}^{2}\right)\end{array}$ & $\begin{array}{l}\text { 引張強度 } \\
\left(\mathrm{kgf} / \mathrm{cm}^{2}\right)\end{array}$ & $\begin{array}{c}\text { ヤング係数 } \\
\left(\times 10^{5} \mathrm{kgf} / \mathrm{cm}^{2}\right)\end{array}$ \\
\hline A & & 265 & 24.9 & 2.47 \\
\hline$\overline{\mathrm{A} 2}$ & & 277 & 26.3 & 2.55 \\
\hline $\mathrm{B}$ & & 274 & 20.4 & 2.39 \\
\hline C & & 286 & 25.6 & 2.53 \\
\hline D & & 286 & 28.1 & 2.38 \\
\hline E & & 288 & 27.2 & 2.41 \\
\hline $\mathrm{F}$ & & 277 & 25.9 & 2.44 \\
\hline $\mathrm{G}$ & & 298 & 25.7 & 2.46 \\
\hline $\mathrm{H}$ & & 285 & 25.6 & 2.44 \\
\hline I 1 & & 279 & 27.1 & 2.34 \\
\hline $\mathbf{J}$ & & 288 & 24.4 & 2.37 \\
\hline $\bar{J} \mathbf{s}$ & & 296 & 26.1 & 2.54 \\
\hline $\mathrm{K}$ & & 350 & 30.0 & 2.63 \\
\hline $\mathrm{L} 1$ & & 298 & 25.8 & 2.50 \\
\hline $\mathrm{T} 1$ & & 291 & 22.1 & 2.33 \\
\hline $\mathrm{T} 2$ & & 883 & 43.3 & 4.15 \\
\hline 龬 & & $\begin{array}{l}\text { 降伏強度 } \\
\left(\mathrm{kgf} / \mathrm{cm}^{2}\right)\end{array}$ & $\begin{array}{l}\text { 引張強度 } \\
\left(\mathrm{kgf} / \mathrm{Cm}^{2}\right)\end{array}$ & $\begin{array}{c}\text { ヤング係数 } \\
\left(\times 10^{6} \mathrm{kgf} / \mathrm{cm}^{2}\right)\end{array}$ \\
\hline & D6 & 3175 & 4820 & 1.89 \\
\hline & D 10 & 3863 & 4924 & 1.82 \\
\hline & D 19 & 4142 & 6118 & 2.03 \\
\hline \multirow{4}{*}{ PLATE } & $12 \mathrm{~mm}$ & 2700 & 4360 & 2.18 \\
\hline & $16 \mathrm{~mm}$ & 2717 & 4516 & 2.24 \\
\hline & $19 \mathrm{~mm}$ & 2700 & 4270 & 2.19 \\
\hline & $22 \mathrm{~mm}$ & 2720 & 4400 & 2.20 \\
\hline
\end{tabular}

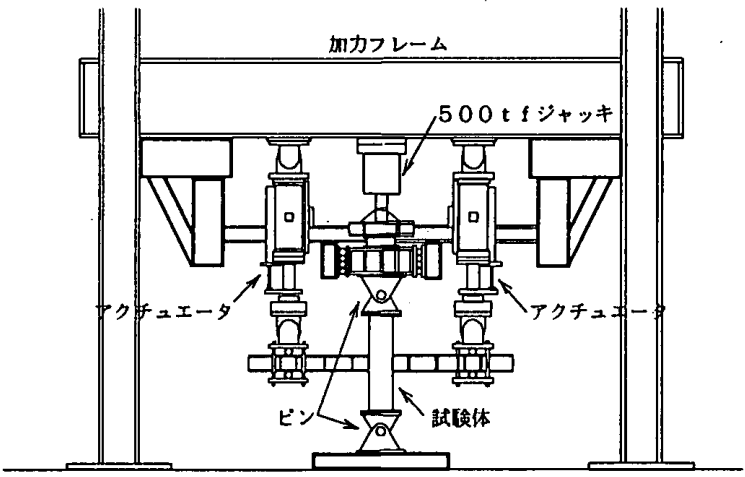

図３加力装䁂 

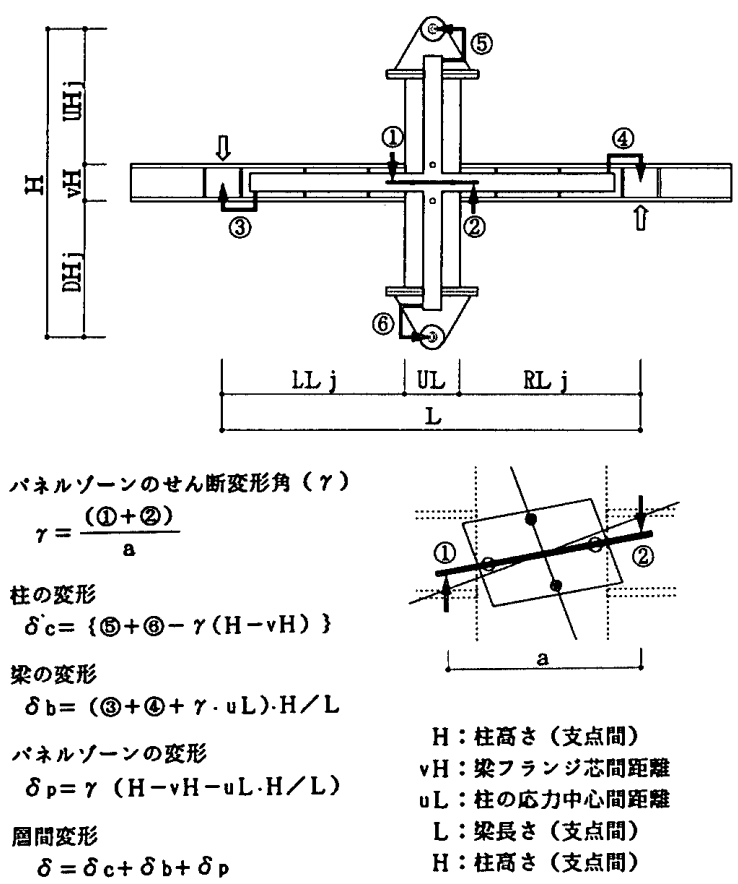

$\mathrm{H}$ : 柱高さ (支点間) vH：柴フランジ芯間距離 $\mathrm{UL}$ : 柱の后力中心間距 L : 架辰さ (支点間) $\mathrm{H}$ : 柱高さ（支点間）

図 4 変形測定方法

いて柱、梁変形 (3)〜 (6) ) を計測し、接合部せん断変形 角は、十字型測定フレームと梁軸線上に取り付けたー字 型测定フレームとの相対変位（11、（2） から求めた。層 間変形は、柱、梁、接合部変形の和として評洒した。

\section{3. 実臨䊅果}

\section{1 破塤経過}

図 5 に基本試験体 $\mathrm{A} 1$ と卜型試験体 $\mathrm{T} 1$ の最終ひび割 れ状況の展開図を示す。ひび割れの発生順は、A〜Jお よびL試験体では、ほぼ共通で、最初に柱の曲げひび割 れが発生し、次いで直交方向エンドプレート端部からの 斜めのひび割れが発生し、鉄骨梁フランジの降伏が、凰 間部材角 $\mathrm{R}=1 / 100 \mathrm{rad}$.から $\mathrm{R}=1 / 50 \mathrm{rad}$.へ向かうサイクルの 途中で生じた後、接合部領域の柱隅筋に沿ってひび割れ が発生した。 $\mathrm{R}=1 / 33 \mathrm{rad}$. 頃からエンドプレートの周辺に エンドプレートの拔け出し、めり込みによるコンクリー トの圧壊がみられた。

$\mathrm{P} C$ 鋼棒で締め付けたK試駺体およびト型の T 試験体 では、柱の曲げひび割れ後、接合部にむ水平のひび割れ が発生したが、鉄骨梁フランジが降伏した後は、梁のみ か変形する性状を示した。

3. 2 層せん断力一層間変位関係

層せん断力一層間変位関係を図6に示す。

層せん断力一層間変位曲線は、 $\mathrm{A} 、 \mathrm{~B} 、 \mathrm{C} 、 \mathrm{E} 、 \mathrm{~F}$ 、

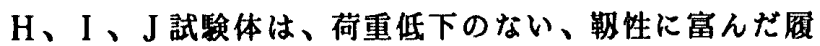
歴性状であった。ループ形状は、変形の增加に伴い、徐 タにスリップ型の形状になる頃向を示している。

エンドプレートを長くしたD 1 試験体では、その倾向

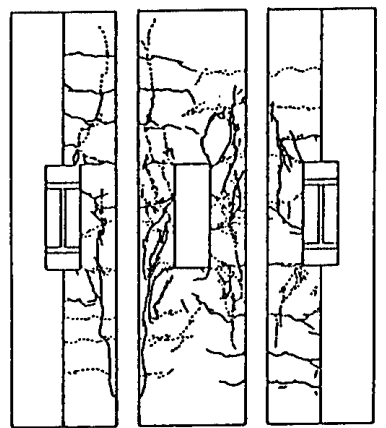

A 1 （基本形）

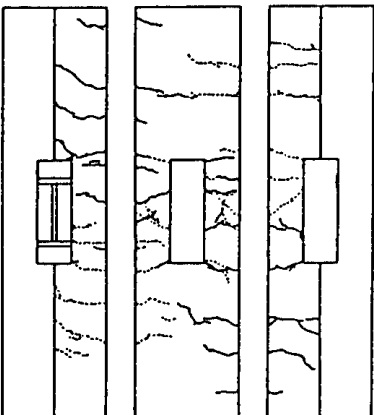

T 1 (ト型)
図5ひび割れ状況（最終）

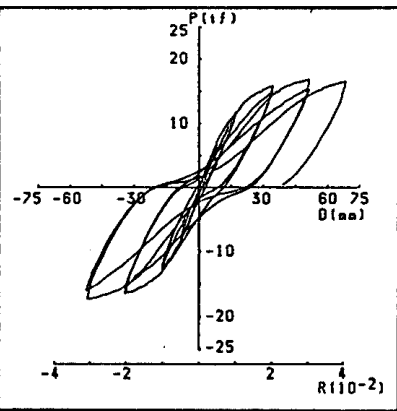

A 1 (基本形)

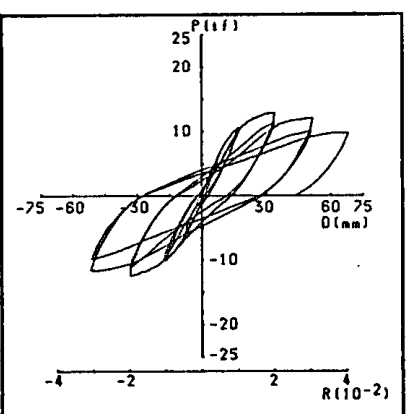

G 1 (エンドフ・レー無し)

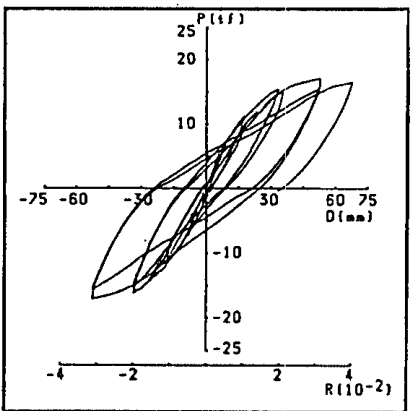

D 1 （エントプレート長大）

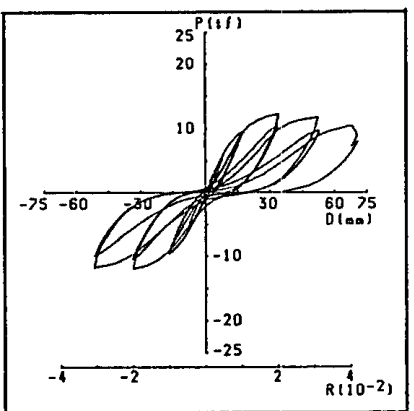

L 1 (梁貫通型)
図6 層せん断力一層間変形関係

は見られず、紡鍕型のループ形状を示した。

接合部中央位置にエンドプレートが無いG 1 試駼体で は、屏間部材们 $R=1 / 33 \mathrm{rad}$.から荷重が低下した。

鉄骨梁が貫通したL 1 試験体では、除荷時に大きなス リップを起こす逆S字型のループ形状を示しだ。

K、T試験体では、鉄骨梁部材の変形を顛薪に表すよ うな、バイリニア型のループ形状であった。

卜型試験体 T 1、T 2では、コンクリート㑷度の違い による影響を比較しようとしたものであるが、梁降伏型 の破壊のため、層せん断力の違いは、あまり無かった。

接合部仕口の特设の異なる K、L試駼体を除くと、新 しい接合部仕口を有する試験体は、接合部中央部分にエ ンドプレートが無い G 1 以外は、最終部材解においてす、 荷重低下がほとんどみられなかった。

本実験は、同一変形で 2 回の繰り返しを行っている。 繰り返しによる影響は、強度低下とループ形状に現れて いる。ループ形状は、変形の增大により違いが顥著にな 
ってくる。特に、耐力低下が生じている試験体では、絽 り返しによりループ面積が小さくなり、梁貫通のL 1 て は、その影響が顕著である。

試験体のひび割れ状況や層せん断力一層間变位曲線、 柱主筋のひずみ状況からみて、A〜JおよびL試験体で は、梁降伏後の接合部破壊型と考えられ、残りの $\mathrm{K} 、 \mathrm{~T}$ 試験体は、梁降伏型と想定される。

3.3接合部中板・斜めスチフナのひずみ

正加力時梁フランジ引張側の梁フランジ線上の、柱面 から $40 \mathrm{~mm}$ 入った位置に水平に貼ったひずみゲージから求 めた接合部内中板ウェフと斜めスチフナのひずみ分布を 図7に示す。

鉄骨梁フランジの降伏は、各試験体共、 $R=1 / 100 \mathrm{rad} . \sim$ $\mathrm{R}=1 / 50 \mathrm{rad}$.に変形が進む途中で起こっている。

基本形状のA 1 では、先に中板が $R=1 / 50 \mathrm{rad}$.で降伏し、 斜めスチフナは、R=1/33rad.で降伏した。

中板を厚くしたB 1 は、斜めスチフナがR=1/50 rad.て 降伏し、中板は、R=1/33rad.で降伏した。

接合部中央位置にエンドプレートが無い G 1 は、斜め スチフナは、R=1/25rad.でようやく降伏したが、中板は 降伏しなかった。これは、上下に分割された接合部仕口 が接合部内で㓮体変形していたものと考えられる。

接合部中央位置に中板の有る J 1 は、降伏時期は A 1 より遅いが、A 1 と同様なひずみ分布形状を示し、接合 部中央位置の中板の有無によるひずみ分布の違いは、見 られなかった。

斜めスチフナの無いF 1 は、エンドプレートからの引 張力を全て中板で受ける試験体であるが、中板の降伏は、 $\mathrm{R}=1 / 50 \mathrm{rad}$.であった。

中板と斜めスチフナの板厚を変えることにより、降伏 時期を制御できることがわかった。しかし、実験では、 中板と斜めスチフナの引張降伏が、接合部強度や首間变 位に与える影辢は、少なかった。

3.4コンクリート圧縮ストラットひずみ

接合部のコンクリート圧縮ストラット位䈯に埋め込ん だモールドゲージ（検長60mm)により測定したコンクリー トのひずみと層せん断力の関係を図8に示す。

モールドゲージの計测位㯰は、図 9 に示すように、接 合部中央に中板の無い形状の A 1、H 1 試験体は、接合 部内を圧縮ストラットが対角線を形成しているとした時 の接合部中央位畏に、また接合部中央位置に直交方向中 板ウェブが有る J 1、L 1 試験体では、2つの圧縮スト ラットが形成されているとした時のストラット方向の接 合部中央位置とした。

コンクリート圧樎ストラットのひずみ值は、一軸圧縮 強度時のひずみが $1800 \mu$ 程度であるのに対して、接合部 変形の增加に伴い、6000 にす関わらず、接合部全体の酎力低下は生じていない。
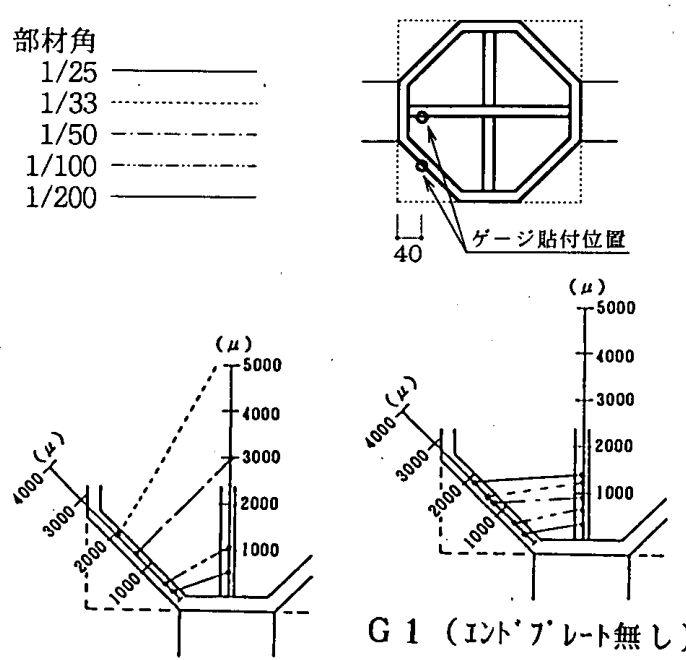

A 1 （基本形）

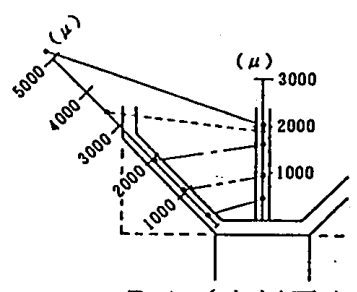

B 1 (中板厚大)

G 1 (エンドプレート無し

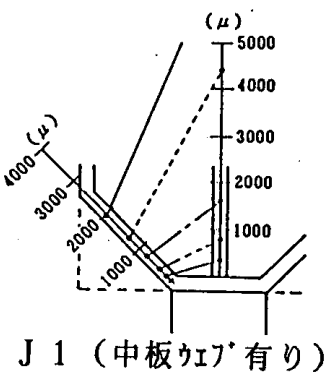

図 7 接合部仕口のひずみ分布

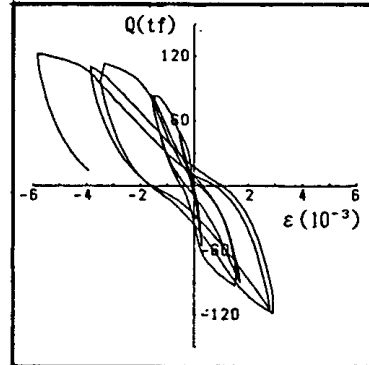

A 1 （基本形）

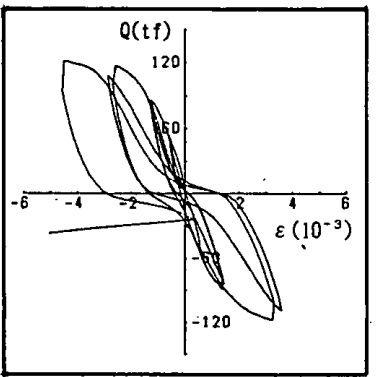

H 1 (直交中板無し)
J 1 （中板ゥエプ有り）

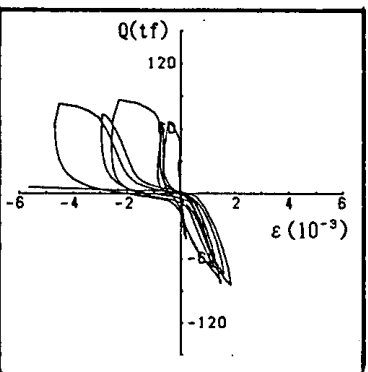

L 1 (梁貫通型)

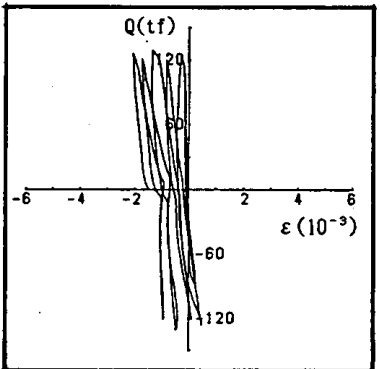

図 8 接合部せん断カーコンクリート圧縮 ストラットひずみ関係

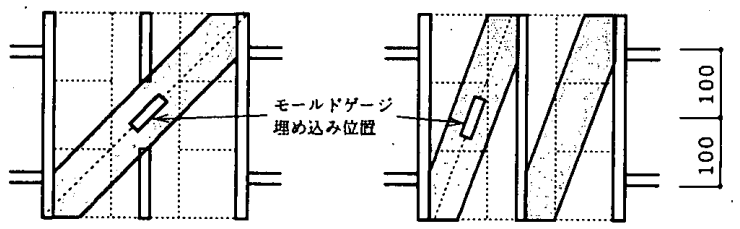

図 9 圧縮ストラット概念図 


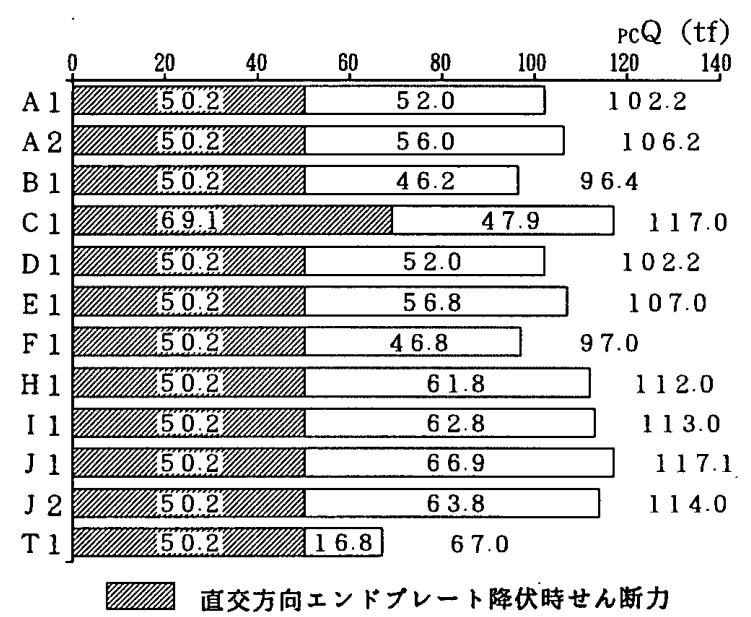

図 10 直交方向エンドプレート降伏時 における接合部せん断力

このことから、接合部仕口形状は、接合部コンクリート の拘束勃果に有効であったことがわかる。

図8に現れている引張ひずみは、モールドゲージとコ ンクリートの付着により計測されたものであり、コンク リート自体の引張ひずみとひび割れ幅を含んでいる。

$\mathrm{J}$ 試験体では、直交方向中板が接合部を 2 分割してお り、直交方向中板を介して2つの圧縮ストラットが形成 されていると考えられ、その時の圧縮ストラットひずみ 值は接合部中央に中板の無い試験体と異なり、最大部材 角時においてす $2000 \mu$ 程度であった。接合部中央を中板 で分割している形状の試験体では、接合部仕口の拘束効 果によるコンクリートの強度上昇は少ないと考えられる。

しかし、同様に直交梁により接合部を2分割している L 1 試験体では、圧箖ストラットのひずみ侹は、变形の 增加に伴い大きな值を示している。

3. 5 直交方向エンドプレート

直交方向エンドプレート降伏時の接合部せん断力を検 討するために、直交方向エンドプレート中央水平位固の 3 カ所に貼った 3 方向ゲージから求めた直交方向エンド プレートのせん断降伏耐力と、降伏時の接合部せん断力 を図 10 に示す。ここで、直交方向エンドブレート降伏 時せん断力は、直交方向エンドプレートが全断面せん断 降伏した時の断面積とせん断降伏強度との積による計算 值である。K 1、T 2 は、最終部材角においても、直交 方向エンドプレートは、せん断降伏しておらず、G 1、 L 1 は、計湘していない。

試験体は、梁降伏型を除けば、J試験体以外は、層間 部材角 $\mathrm{R}=1 / 100 \sim 1 / 50 \mathrm{rad}$.の間に直交方向エンドプレート は、せん断降伏している。接合部中央に中板ウェブの有 る $\mathrm{J}$ 試験体は、 $\mathrm{R}=1 / 33 \sim 25 \mathrm{rad}$.の間にせん断降伏した。

$\mathrm{J}$ 試験体では、直交方向エンドブレート中央部分の昙 㑡に直交中板が付いており、これがエンドプレートの変 形を拘束したため、降伏時期が遅れたすのと考えられる。

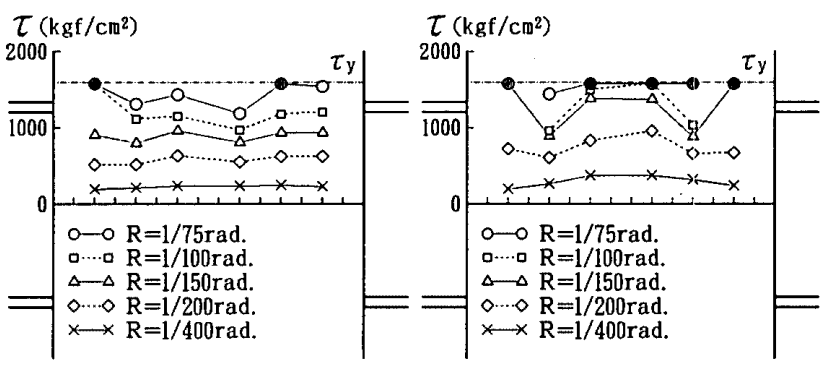

J 1 (中板的ブ有り） L 1 (梁貫通型）

図 11 中板のせん断応力度分布

接合部中央部分に中板が無く、直交方向エンドプレー トのある試験体では、多少のばらつきはあるが、接合部 せん断力が $100 〜 110 \mathrm{tf}$ 程度で直交方向エンドブレートは、 せん断降伏している。接合部せん断力は、これ以後む 1 割程度の強度上昇がある。

実験結果から、試験体は、直交方向エンドプレートが 降伬した後に、コンクリート負担分が最大虫度に達した ことがわかる。

直交方向エンドプレート降伏時の接合部せん断力にお けるコンクリートの負担分は、50〜60tf程度であり、実 伢における接合部最大せん断力時のコンクリートの負担 分は、70〜80tf程度であった。

実験での接合部のコンクリート负担分は、 R C 造の接 合部コンクリート強度を0. $3_{C} \sigma_{B} \cdot b_{j} \cdot D_{j}{ }^{6)}$ とした時の值 （約50tf）よりむ大きくなっている。これは、接合部仕 口の拘束効果の影響と考えられる。

3.6中板ウェブのせん断応力分布

接合部中央に中板ウェフのある J 1 試験体と梁貫通型 のL 1 試験体について、中板ウェプの接合部中央位置に 水平方向に貼った 3 方向ゲージから求めたせん断応力度 分布を図 11 に示す。

両試験体共、部材角 $R=1 / 50 \mathrm{rad}$.で、ウェプ中央位置 は、ほぼ全領域がせん断降伏している。

変形の小さい時点のせん断応力度分布は、中央位圈の 直交方向中板ウェブの影整はあるが、J 1 では、ほぼ一 栐なせん断応力度分布となっており、L 1 は、山形の分 布形状となっていた。

\section{4.接合部甘ん断耐力}

4. 1 接合部せん断カーせん断変形関係

接合部せん断力一せん断変形関係を図 12 に示す。 せん断変形は、梁降伏した試験体とJ試験体を除くと、 部材角 $\mathrm{R}=1 / 50 \mathrm{rad}$.から增加し始める。中板ウェブのある $\mathrm{J}$ 試験体では、部材角 $\mathrm{R}=1 / 33 \mathrm{rad}$. から変形が增大した。 本実験では、せん断変形角が $\gamma=6 \sim 10 \times 10^{-3} \mathrm{rad}$. でほ ぼ最大せん断力に達している。 


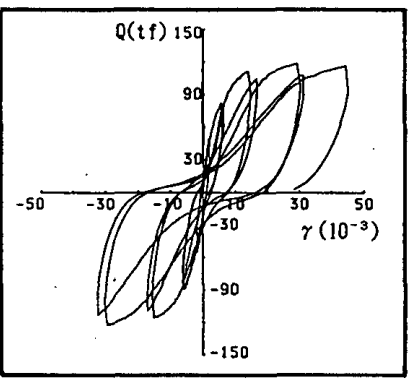

A 1 (基本形)

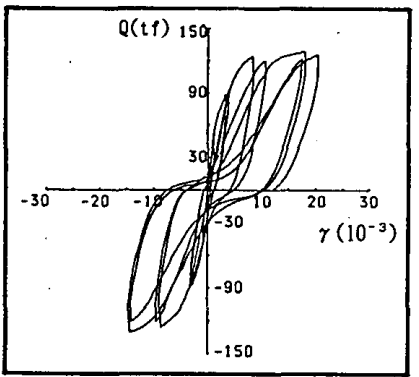

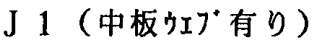

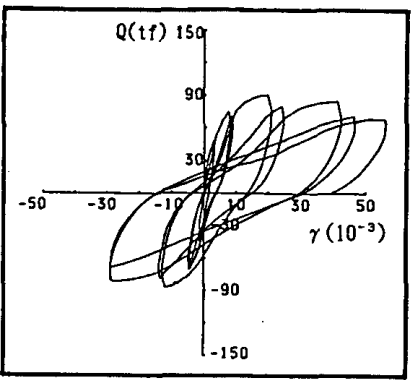

D 1 （エントフプレート長大）

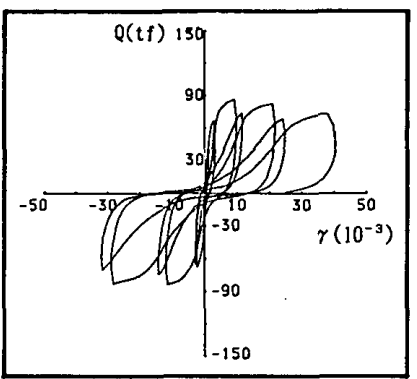

L 1 （梁貫通型）
図 12 接合部せん断カーせん断変形関係

\section{2 接合部最大せん断力の比較}

実験結果の接合部最大せん断力と既往の強度式による 計算値の一覧を表 4 に示す。接合部に作用するせん断 力 $\mathrm{PC} Q$ は、次式を用いて算定した。

$$
{ }_{\mathrm{PC}} \mathrm{Q}=\left(\mathrm{M}_{\mathrm{BL}}+\mathrm{M}_{\mathrm{BR}}\right) / \mathrm{vh}-\mathrm{Q}_{\mathrm{c}}
$$

ここで、 $\mathrm{Pc} Q$ は接合部に作用する柱側せん断力、 $\mathrm{M}_{\mathrm{BL}}$ 、 $\mathrm{M}_{\mathrm{BR}}$ は左右の梁モーメント、vhは梁のフランジ芯間距離、 Q 。は柱せん断力である。

また、試験体中 K 1 およびT 1、2 は、梁降伏型試験 体であるので、検郡の対象からは除外し、F 1 は、接合 部せん断変形の計測值が乱れているために、最大せん断 耐力のみの部価とした。

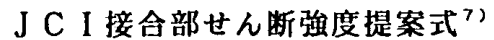

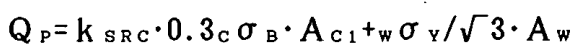

ただし、 $\mathrm{k} \mathrm{sRc}_{\text {s }}$ 拘束度に応じた有効係数

$$
=1.07\left(\mathrm{~L} 1 \text { は、 } \mathrm{k}_{\mathrm{SRC}}=0.77\right)
$$

${ }_{\mathrm{C}} \sigma_{\mathrm{B}}$ ニコンクリート圧縮強度

$\mathrm{A}_{\mathrm{c} 1}=$ 柱幅 $/ 2 \times$ 柱せい

${ }_{w} \sigma_{\mathrm{Y}}=$ 鉄骨の降伏応力度

$\mathrm{A}_{w}=$ 鉄骨の断面積

$\mathrm{A}_{\mathrm{C} 1}$ の有効幅は、S R C 基準に準じ、梁が鉄骨だけであ るので柱幅の $1 / 2$ とした。Awは、接合部高さ中央の水平 断面位置にある鉄骨断面積であり、中板ウェフの無い試 験体（J、L以外）では、直交エンドプレート断面程の みとなる。

実験值は、J C I 提案式に対して、やや大きめの結果 となった。計算值に対する実験値の比（図13(a)) の平 均値は、1.19であるが、これは、接合部中央に中板のあ るJ試駼体す含んでいるためである。J試験体を除くと、 比の平均値は、1.38となる。
表 4 接合部せん断力実験値己計算値

(tf)

\begin{tabular}{|c|c|c|c|c|}
\hline & $\begin{array}{c}\text { 実験值 } \\
\mathrm{PCQ}\end{array}$ & $\begin{array}{c}\text { 計算值 } \\
\text { 式(2) }\end{array}$ & $\begin{array}{c}\text { 計算値 } \\
\text { 式(3) }\end{array}$ & $\begin{array}{c}\text { 計算值 } \\
\text { 式(4) }\end{array}$ \\
\hline A 1 & 121.3 & 88.5 & 69.4 & 101.2 \\
\hline A 2 & 125.4 & 90.2 & 69.9 & 103.5 \\
\hline B 1 & 124.5 & 89.8 & 75.7 & 102.9 \\
\hline C 1 & 121.9 & 110.4 & 70.2 & 124.2 \\
\hline D 1 & 120.5 & 91.5 & 70.2 & 105.3 \\
\hline E 1 & 134.8 & 91.8 & 70.2 & 105.6 \\
\hline F 1 & 97.7 & 90.2 & 69.9 & 103.5 \\
\hline G 1 & 90.7 & 43.0 & 70.6 & 57.4 \\
\hline H 1 & 121.9 & 91.3 & 70.1 & 105.1 \\
\hline I 1 & 117.5 & 90.5 & 78.0 & 103.9 \\
\hline J 1 & 137.5 & 159.2 & 107.9 & 122.9 \\
\hline J 2 & 129.6 & 160.3 & 107.9 & 124.4 \\
\hline L 1 & 87.5 & 87.0 & 90.6 & 87.0 \\
\hline
\end{tabular}

（2）式のk sRcは、ディテールの工夫により変動する ちのであり、本研究のような仕口形状では、拘束効果が 大きく、 $\mathrm{k} \mathrm{sRC}_{\mathrm{sR}}=1.8$ 程度と報告されている4)。

$\mathrm{k} \mathrm{sRc}$ を本実験結果から求めると、接合部中央位置に中 板ウェプの無い試験体では、Awは、直交方向エンドブレ 一ト断面樌のみであり、 $\mathrm{k} \mathrm{SRC}_{\mathrm{SR}}=1.81$ となる。(図 $13(\mathrm{~b})$ )

接合部中央位四に中板ウェブの有る試駼体では、 $\mathrm{A}$ wは、 直交方向エンドプレートと中板ウェブの断面稓の和とし て求めると、k sic $=0.4$ となり、コンクリートの拘束効 果を過小評価する結果となってしまう。

これは、図9に示すように、コンクリート圧縮ストラ ットが 2 分割されストラット幅が狭くなること、コンク リート拘束効果が弱くなること、および鉄骨部分の断面 程の部価を直交方向エンドプレートと中板ウェプの断面 稳の和としていることが考えられるが、今後の检討課題 である。

$\mathrm{S} \mathrm{RC}$ 規準接合部せん断強度式 ${ }^{8)}$

$$
\begin{aligned}
& { }_{J} \mathrm{M}_{\mathrm{U}}={ }_{\mathrm{C}} \mathrm{V}_{\mathrm{E}}\left({ }_{J} \mathrm{~F}_{\mathrm{s}} \cdot{ }_{j} \delta{ }_{\mathrm{W}} \mathrm{P} \cdot{ }_{\mathrm{W}} \sigma_{\mathrm{Y}}\right)+1.2_{\mathrm{S}} \mathrm{V} \cdot{ }_{\mathrm{S}} \sigma_{\mathrm{Y}} / \sqrt{ } 3 \\
& \mathrm{Q}_{\mathrm{p}}=\mathrm{J}_{\mathrm{u}} / \mathrm{vh} \\
& { }_{c} V_{E}={ }_{c} b / 2 \cdot{ }_{B B} d \cdot{ }_{m} c d \\
& \text { =接合部のコンクリート部分の有効体程 } \\
& \mathrm{F}_{\mathrm{s}}=\text { 接合部のコンクリートのせん断强度 } \\
& , \delta=\text { 接合部の形玦による係数 } \\
& { }_{\mathrm{WP}} \cdot{ }_{\mathrm{w}} \sigma_{\mathrm{Y}}=\text { せん断補強筋のせん断強度 } \\
& s \mathrm{~V}=\mathrm{s}_{\mathrm{r}} \cdot_{\mathrm{sB}} \mathrm{d} \cdot \operatorname{sic}_{\mathrm{s}} \mathrm{d} \\
& \text { = 接合部の鉄骨のウェブの体積 } \\
& { }_{s} \sigma_{\mathrm{Y}}=\text { 鉄骨の降伏応力度 } \\
& \mathrm{c} b=\text { 柱の幅 } \\
& \text { \&B d =梁フランジの重心間距䧸 } \\
& \mathrm{mc} d=\text { 柱の左右の主箭間距離 } \\
& s \mathrm{t} \text { 、柱はり接合部の鉄骨のウェブの厚さ } \\
& { }_{B} \mathrm{C} d \text { = 柱フランジの重心間距雜 }
\end{aligned}
$$

ここで、 $\mathrm{s} V$ 中の $\mathrm{scd}$ は $_{\mathrm{mc}} \mathrm{d}$ とし、梁のフランジ芯阔 距離中にある中板面積のみを評価した。

S R C 規染式に対して、実駼値は、大きめの值であり、 計算値に対する実駼値の比（図 $13(\mathrm{c})$ )) の平均値は、 1.54であった。接合部中央に中板が有るJ試験体と梁買 
通型の L 1 試験体では、計算値に対する実駼値の此の平 均值は、1.15となり、良い対応を示している。

しかし、S R C 規準式では、本実験のような接合部仕 口は考虑されていないこと、柱 R C・梁 S 構造における 鉄骨ウェフの体積を求める際の $\mathrm{c} \mathrm{d}$ の定義の方法が不明 確なことか、S R C 規準式を準用する時の問題点となる。 4. 3 接合部せん断酎力

仕口形状の違いによる影幚で比較すると、 (1)中板ウェフ厚さの違いによる影䅧はみられなかった。 (2)エンドブレートの厚さの違いによる影䪪はみられない。 (3梁成の違いによる影響はみられなかった。

(4)直交方向中板の有無は、接合部せん断力に影䪪しない。 (ㄷ)斜めスチフナは、コンクリート拘束効果に有効である。 (6)接合部中央にエンドブレートが無いものは、 $0.3_{c} \sigma_{g}$ と した時の 2 倍以上の強度であった。 (7)中板に水平テーパーを付けたものは、接合部せん断耐 力の上昇に効果があった。

8接合部中央に中板の有るむのは、無いむのに比べて、 約10tfの酎力上昇であった。

既往の接合部強度式は、コンクリート負担分と鉄骨負 担分の和で評価している。この仮定は、両者が十分に強 度を発揮した時に成り立つ。即ち、勒性のある鉄骨部分 が先に強度に達した後、コンクリート部分が強度に達す ることが必要である。本試験体です、鉄骨部分である直 交エンドブレートが先に降伏し、その後コンクリートが 強度を発揮する結果となっている。

コンクリートの接合部強度と有勃断面積については、 種々の提案があるが、本実験では、柱幅と梁幅の影䍌に ついては検討していない。

そこで、有効断面積は、S R C 規準を参考に、柱せい X柱幅 $/ 2$ とし、接合部強度は、 $0.3 \mathrm{c} \sigma_{\text {в }}$ としてコンクリ 一ト拘束効果の影箅を係数で評価する方法を探用した。

また、斜めスチフナの無いむの、接合部をウェブ中板 により 2 分割されたものは、拘束効果が小さいと考えた。

実験結果を基に J C I 提案式と S R C 梘準を参考に、 実験結果を評洒する式として式（4）を考えた。コンク リート部分は、J C I 提案式のように拘束勃果を保数で 考え、鉄骨部分は、ウェブ断面を評価することを基本に、 本実験の接合部基本形のようなウェフ中板の無いむので は直交方向エンドプレートを評価した。

$$
\begin{aligned}
& Q_{\mathrm{P}}=\mathrm{k} \cdot 0.3_{\mathrm{c}} \sigma_{\mathrm{B}} \cdot \mathrm{A}_{\mathrm{c}}+_{\mathrm{W}} \sigma_{\mathrm{Y}} / \sqrt{3} \cdot \mathrm{A}_{\mathrm{B}} \\
& \mathrm{k}=\text { 拘束勃果係数 } \\
& =1.8(\mathrm{~J} タ イ フ ゚=1.07, \mathrm{~L} 1=0.77) \\
& { }_{\mathrm{C}} \sigma_{\mathrm{B}}=\text { コンクリート压縮強度 } \\
& \mathrm{A}_{\mathrm{c}}=\text { 柱せいメ柱幅 } / 2 \\
& \text { w } \sigma_{\mathrm{Y}}=\text { 鉄骨降伏応力度 } \\
& \mathrm{A}_{\mathrm{s}} \text { ニウェフフ鉄骨断面積（接合部内にウェフの無い }
\end{aligned}
$$
とした。

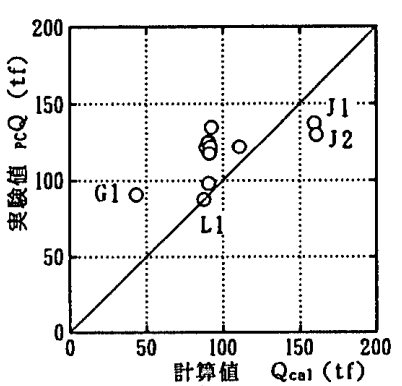

(a) 式(2) $\left(\mathrm{KSRC}_{\mathrm{SRC}}=1.07\right)$

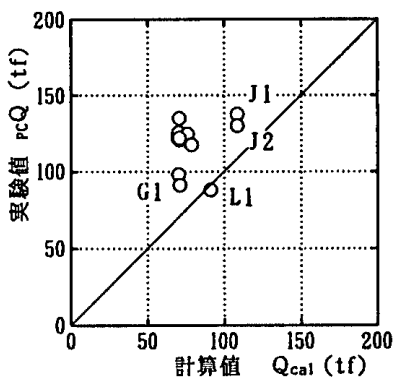

(c) 式(3)

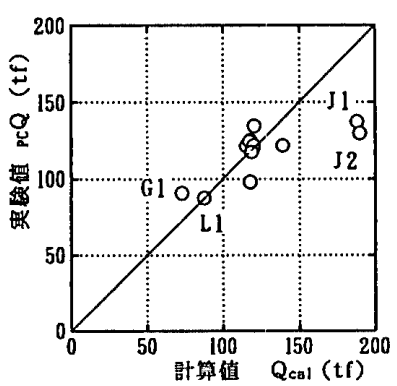

(b) 式(2) $(\mathrm{KsRC}=1.8)$

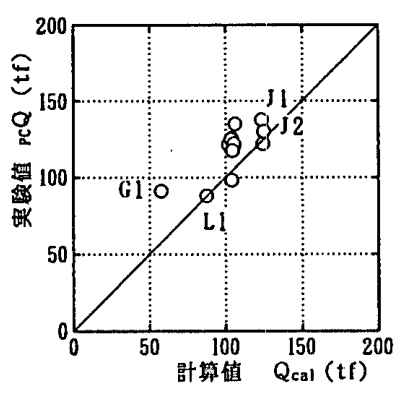

(d) 式(4)

図 13 接合部せん断力実験值と計算值の比較

式（4）は、実験結果とよい対応を示し、計算值に対 する実験值の比は、1.03であった。（図 $13(\mathrm{c}))$

しかし、ェンドプレートの無いG 1 については、検討 の余地を残す。

\section{5.接合部の网性評洒}

柱を $\mathrm{R} C$ 造、梁を $\mathrm{S}$ 造とした混合構造接合部のせん断 㽤性に関する研究に関しては、坂口 ${ }^{(0)}$ が梁貫通型でふさ ぎ板が接合部を囲っている形状については恰討している が、柱貫通型のようなタイプについては、検討例は少な い。しかし、部材の挙動を架構に反映させるためには、 通切な接合部涠性の伻価を行わなければ架棈の設計を行 うことは困難である。

そこで、開発した接合部ディテールの復元力特性につ いてのモデル化を恰討する。

剛性を評洒するにあたり、接合部を構成する部材であ る鉄骨部分とコンクリート部分についてそれぞれの復元 力をモデル化し、その重ね合わせとして接合部全体の復 元力特性モデルを考える。

\section{1鉄骨モデル}

図 14 に鉄骨部分のせん断応力一せん断変形のモデル を示す。このモデルでは、鉄骨のせん断降伏以㣪の耐力 上昇は考虑していない。

初期剛性は、鋼材の弾性せん断剛性 $\left(\mathrm{G}_{\mathrm{s}}\right)$ とする。 銅材を完全バイリニアとすると、せん断降伏応力時 $\left({ }_{w} \sigma_{y} / \sqrt{ } 3\right)$ のせん断变形は、 $\gamma=2 \times 10^{-3} \mathrm{rad}$. 程度とな るが、実稌における鉄骨部分のせん断降伏応力時の変形 は、 $\gamma=4 \sim 6 \times 10^{-3} \mathrm{rad}$.程度であり、他の研究 ${ }^{11112) に ~}$ 


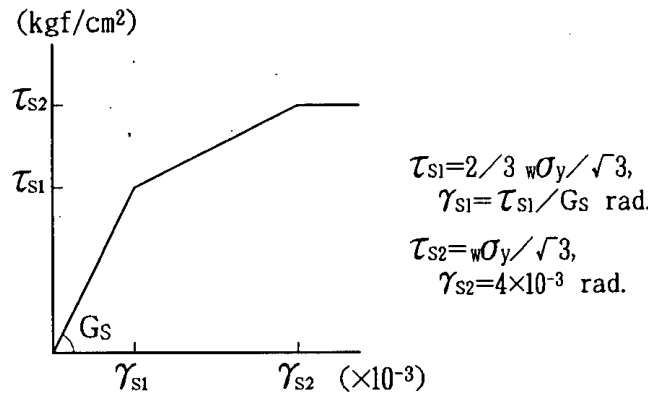

図 144 鉄骨のせん断応力ーせん断変形角モデル
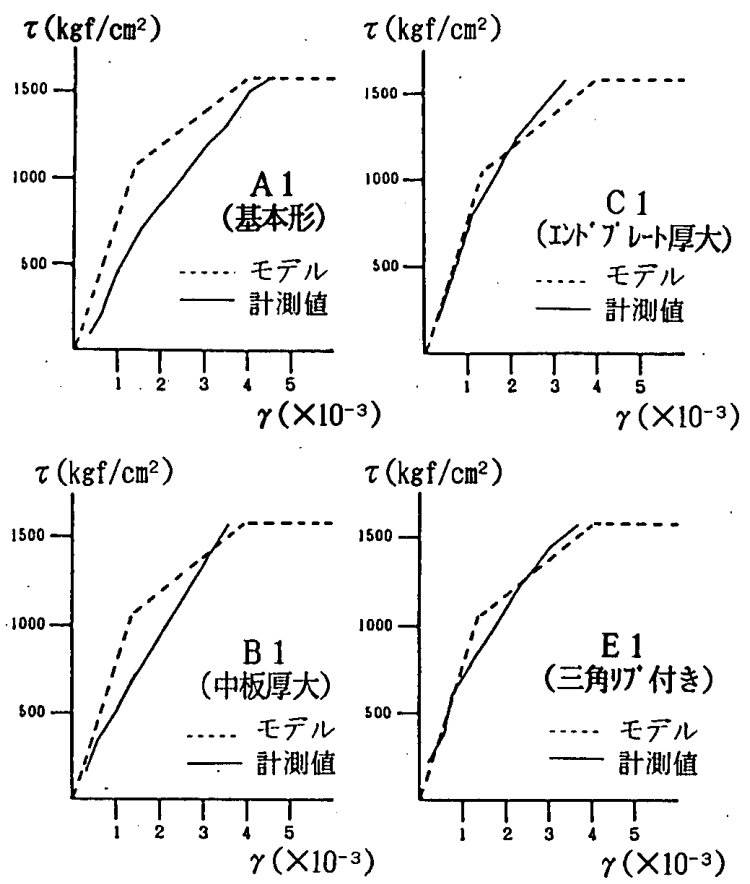

図 15 直交方向エンドプレートの せん断応力一せん断変形角

よれば、 $\gamma=3 \sim 5 \times 10^{-3} \mathrm{rad}$. 程度と報告されている。こ こでは、せん断降伏応力時の変形を $\gamma=4 \times 10^{-3} \mathrm{rad}$.とし た。

第 1 折れ点は、ウェブまたは、エンドプレート中央位 置がせん断降伏した時のせん断応力分布を2次曲線分布

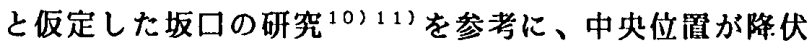
した時の平均せん断応力として、第 1 折机点のせん断応 力 $\left(2 / 3 \cdot{ }_{w} \sigma_{y} / \sqrt{3}\right)$ を決めた。

初期剛性 : $\mathrm{G}_{\mathrm{s}}=\mathrm{E}_{\mathrm{s}} / 2(1+\nu)$

第 1 折饥点: $\tau_{s_{1}}=2 / 3 \cdot{ }_{w} \sigma_{y} / \sqrt{ } 3 、 \gamma_{s_{1}}=\tau_{s_{1}} / G_{s} \mathrm{rad}$. 第2 折れ点: $\tau_{\mathrm{s} 2}={ }_{\mathrm{w}} \sigma_{\mathrm{v}} / \sqrt{3} 、 \gamma_{\mathrm{s} 2}=4 \times 10^{-3} \mathrm{rad}$.

図 15 に実験における直交エンドプレートのせん断応 力とせん断変形関係を示す。

鉄骨部分のせん断応力一せん断変形モデルと実験結果 との対応は、初期剛性の実験結果は、やや低めの㑯向を 示した。しかし、その負担力は、せん断降伏応力に達し ており、実験における鉄骨部分のせん断降伏時のせん断 変形は、 $\gamma=4 \sim 6 \times 10^{-3} \mathrm{rad}$. 程度であった。せん断降伏 時の変形を $\gamma=4 \times 10^{-3} \mathrm{rad}$.としたモデルとの刘応は、良

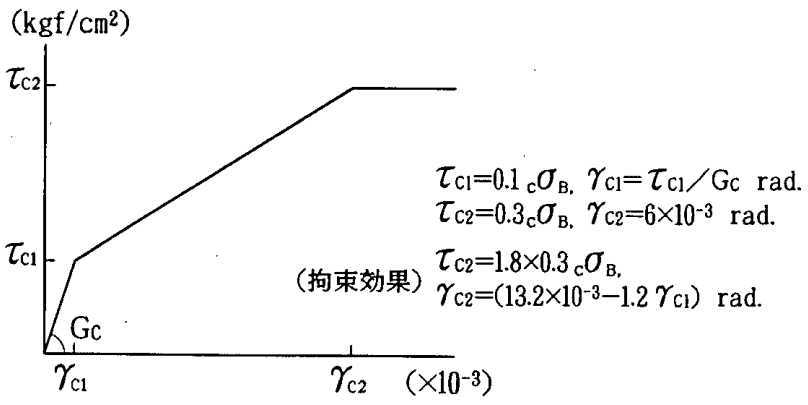

図 16 コンクリートのせん断応力ーせん断変形角モデル

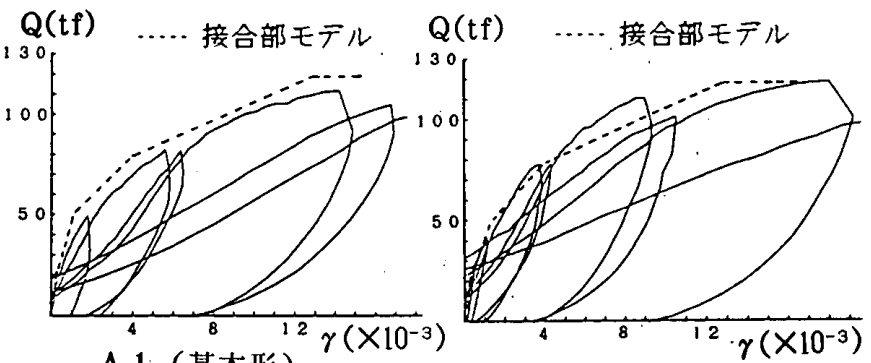

A 1 (基本形)

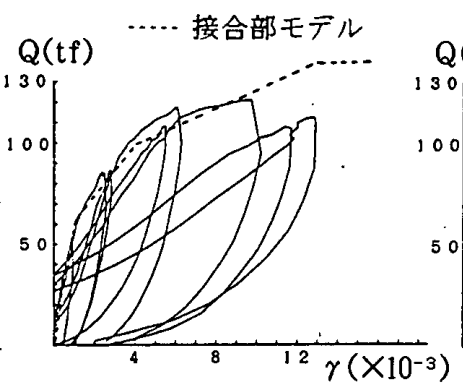

C 1 （エト゚・・ート厚大）
B 1 (中板厚大)

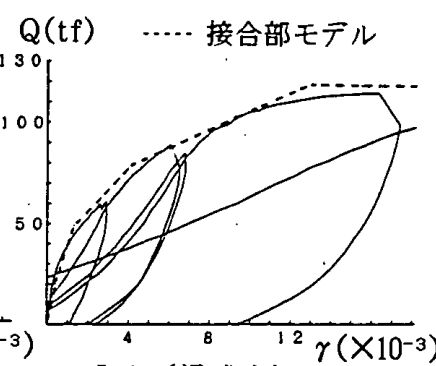

I 1 (梁成大)

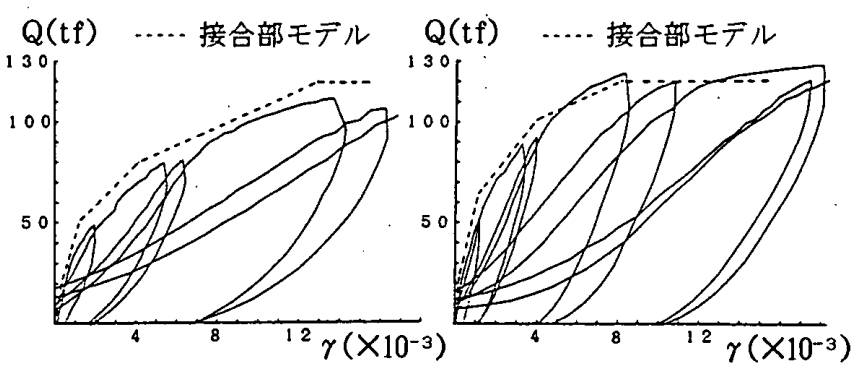

H 1 （直交方向中板無し）

$\mathrm{J} 1$ (中板りエ7*有り)

図 17 接合部せん断力一世ん断変形の比較

好である。

5.2コンクリートモデル

図 16 にコンクリート部分のせん断応力一せん断変形

のモデルを示す。

初期㣚性は、コンクリートの弾性せん断嗍性 $\left(\mathrm{G}_{\mathrm{c}}\right)$ と し、第 1 折れ点をひび割れ強度 $\left(0.1_{\mathrm{C}} \sigma_{\mathrm{B}}\right)$ とした。 コンクリートの接合部せん断耐力は、鉄筋コンクリー 卜終局強度型耐震設㖕指針 ${ }^{6)}$ における接合部せん断強度 $\left(0.3_{C} \sigma_{B}\right)$ を用いた。

実験結果では、接合部せん断変形が增大し始めるのは、 部材角 $R=1 / 100 \mathrm{rad}$.からであり、この時の接合部せん断変 形は、 $\gamma=6 \times 10^{-3} \mathrm{rad}$.程度であった。

コンクリート部分の接合部せん断䖪度時 $\left(0.3_{\mathrm{c}} \sigma_{\mathrm{B}}\right)$ の 
変形を $\gamma_{\mathrm{c} 2}=6 \times 10^{-3} \mathrm{rad}$. とし、拘束効果のあるものは、 この点を通り、 $\tau_{\mathrm{c} 2}=1.8 \times 0.3_{\mathrm{c}} \sigma_{\mathrm{B}} 、 \gamma_{\mathrm{C} 2}=\left(13.2 \times 10^{-3}\right.$ $-1.2 \gamma_{\mathrm{c}_{1}}$ ) $\mathrm{rad} . の$ 点までせん断強度が上昇するすのと仮定 した。

\section{初期㴊性 : $\mathrm{G}_{\mathrm{c}}=\mathrm{E}_{\mathrm{c}} / 2(1+\nu)$}

第 1 折れ点： $\tau_{\mathrm{c}_{1}}=0.1_{\mathrm{C}} \sigma_{\mathrm{B}} 、 \gamma_{\mathrm{c}_{1}}=\tau_{\mathrm{c}_{1}} / \mathrm{G}_{\mathrm{crad}}$.

第2折机点: $\tau_{\mathrm{C}_{2}}=0.3_{\mathrm{C}} \sigma_{\mathrm{B}} 、 \gamma_{\mathrm{C}_{2}}=6 \times 10^{-3} \mathrm{rad}$.

(拘束効果) : $\tau_{\mathrm{c} 2}=1.8 \times 0.3_{\mathrm{c}} \sigma_{\mathrm{B}}$ 、 $\gamma_{\mathrm{c}_{2}}=\left(13.2 \times 10^{-3}-1.2 \gamma_{\mathrm{c}_{1}}\right) \mathrm{rad}$.

\section{3 接合部剛性}

鉄骨モデルとコンクリートモデルを重权合わせた接合 部モデルと実駼における接合部のせん断力一せん断変形 関係を図 17 に示す。

鉄骨モデルについては、直交方向エンドプレート（J 1 では、ウェフ鉄骨部分）のせん断力とせん断降伏時の せん断変形関係をモデル化し、コンクリートモデルにつ いては、実験結果における接合部せん断変形の增大が、 $\gamma=6 \sim 10 \times 10^{-3} \mathrm{rad}$. 程度であること、そして拘束効果の 影製による酎力上昇とコンクリートのせん断変形を考慮 したモデル化を行った。

接合部モデルと、実験におけるせん断カーせん断変形 举動と比較すると、接合部モデルの方が䀠性がやや高い 㑯向にあるが、実験結果を初期から終局まで良く評価し ており、せん断変形については、拘束効果を考虑するこ とが有効であることを示している。また、ウェブ鉄骨を 科価し拘束勃果が小さいJタイプについてす、接合部モ デルは実験値と良い対応を示している。

\section{6。と的}

柱を R C 造、梁を S 造とした混合構造接合部の接合部 仕口をパラメータとした実験を行い、混合構造接合部の せん断酎力を検討し、接合部剛性の評価を行った。

接合部せん断酎力は、本実験の接合部試験体では、鉄 骨部分が先に降伏し、コンクリート部分がその後に最大 耐力に達することから铁骨部分とコンクリート部分の負 担せん断力の累加と仮定し、実跧結果から、コンクリー トの拘束効果の影䈍を係数とした接合部せん断耐力式を 検討した。計算式は、実験結果と良好な対応がみられた。 接合部剛性については、鉄骨部分とコンクリート部分 のせん断応力ーせん断変形モデルを組み合わせることで、 本実軻のような接合部仕口形状を持つ接合部のせん断応 カーせん断変形のモデルを提䋈した。

提案した接合部モデルは、本実鈳に用いた接合部基本 形のようなエンドブレート、中板、斜めスチフナで構成 された接合部仕口を燠用範囲としたすのである。

鉄骨部分については、せん断降伏時のせん断変形を、 コンクリート部分については、コンクリートの拘束訤果
によるせん断変形の增大分を考虑したモデルである。接 合部モデルは、実験における接合部せん断力ーせん断変 形举動と最大せん断耐力時まで良い対応を示した。

混合楛造接合部のせん断耐力一せん断変形を求めるこ とで、架棈の設計を検討するための資料になるむのと考 える。

甜 辞

論文をまとめるに当たり、千葉大学大学院自然科学研 究科博士稞程米澤健次氏には、実験計画に御協力を頂き ました。ここに、感謝の意を表します。

\section{考支苚}

1）西村泰志、南宏一：はり $S ・$ 柱 RCで構成される内部柱は り接合部の応力伝達機構、日本建築学会棈造系諭文報告乗、 No. 401, pp.77 85, 1989.7

2）坂口昇：鉄䈈コンクリート柱と鉄骨梁で構成される柱梁接 合部パネルのせん断酎力、日本建留学会满造系論文報告集、 No. 428, pp. $69 \sim 78,1991.10$

3）传蔡龍生、成原弘之、松原正安：鋼管コンクリート仕口を

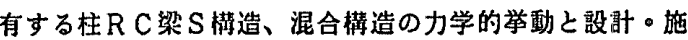
工に関するシンボジゥム論文集、日本コンクリート工学協 会、pp. 77〜84, 1991. 12

4）米沢健次、饭塚信一、野口博：柱 R C。梁 S 混合㩐造接合 部の耐震性能に関する実駼的研究、コンクリート工学年次 踰文報告集、Yol. 14 No.2,pp.735 740, 1992.6

5）笠松照親、饭塚信一、野口博：柱 R C。梁 S で構成された 混合㭢造接合部の酎縟性能に関する研究（その 1、2)、日

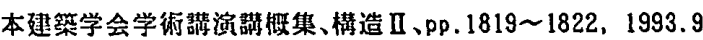

6）日本建筑学会：鉄筋コンクリート造建物の終局強度型耐震 群㽗指針・同解説、1990.11

7）日本コンクリート工学協会：混合構造研究委員会報告集、 1991.12

8）日本建築学会：鉄骨鉄筋コンクリート構造計算規準。同解 説、 1987.6

9）森田耕次他：鉊直スチフナ形式・SRC柱一Sはり接合部 の力学的挙動に関する研究、日本建築学会構造系諭文報告 集、No.413，pp.53〜64，1990.7

10）坂口昇：鉄筋コンクリート柱と䠶骨梁で構成される架構の

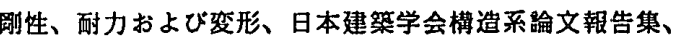
No. 437, pp.125 134, 1992.7

11）坂口昇：鉄筋コンクリート柱と跌骨梁で棈成される柱梁接 合部バネルのせん断力ー变形関俰、日本建築学会構浩系綸 文報告集、No.429，pp.55 64，1991.11

12）岡田宏、武田专一、竹本清：S + S R C 構造の実験的研究 (その 2 ）柱はり接合部の举動と耐力、日本建築学会大会、 pp. 1511 1412, 1972.10

(1993 年 10 月 8 日原稿受理, 1994 年 5 月 2 日採用決定） 